\title{
25
}

\section{Black Swans and the Emergence of Unemployment Insurance in the First Half of the Twentieth Century}

\section{Herbert Obinger and Carina Schmitt}

\section{Introduction}

Compared to other branches of the welfare state, unemployment compensation differs in at least two respects. It was enacted later and in far fewer countries and was the first social protection scheme that was subject to massive retrenchment before 1945. This chapter examines the introduction and spread of unemployment compensation schemes across the globe up to 1950. We argue that unemployment insurance was (and still is) the most controversial social protection scheme which, in addition, is intimately tied to the existence of complementary institutions such as capitalist labour markets and employment exchanges. Programme adoption therefore only occurred in economically developed countries and its introduction was crucially facilitated by "black swans" (Castles 2010) such as interstate war and deep economic crises. Both world wars

H. Obinger $(\bowtie) \bullet$ C. Schmitt

University of Bremen, Bremen, Germany

e-mail: herbert.obinger@uni-bremen.de; carina.schmitt@uni-bremen.de

(C) The Author(s) 2022 
and the Great Depression set off shock waves across the globe which not only created tremendous social need but also opened a (short) window of opportunity for the introduction and reform of unemployment insurance.

\section{The Controversies Over and Prerequisites of Unemployment Insurance}

The introduction of unemployment insurance was highly controversial with moral, political and economic objections being voiced against programme adoption. Historically, the most important moral objection was that unemployment compensation would provide income support to able-bodied people who are capable of working. Unemployment was typically attributed to individual characteristics such as idleness or moral misconduct (e.g. alcoholism). Welfare provision to the "work-shy" was therefore considered a reward for indolence (Alber 1981). Politically, employers feared that unemployment insurance would increase the power of the unions by imposing a "reservation wage" and filling their strike funds. Agrarian interests also strongly opposed unemployment insurance because unemployment was considered an urban problem for which farmers refused to pay. In economic terms, the discussion revolved around the question whether "unemployment is insurable" at all (Stewart 1932, 36). The key issue was moral hazard. Many insurance experts argued that unemployment "is not random in general, but is in the majority of cases willingly and deliberately caused by employees or employers" (Schaertlin 1904, 4-5, own translation). A related problem was adverse selection. The only solution to cope with this problem is mandatory insurance which, however, was politically contested. Finally, it was argued that business cycle fluctuations are unpredictable, which would complicate any sound funding of this programme.

Apart from these controversies and technical difficulties, the introduction of unemployment insurance is only likely under particular economic and institutional conditions. Unemployment is a phenomenon that is intimately tied to the rise (and crises) of modern capitalism with its contract-based formal labour market. While unemployment insurance 
was more or less superfluous in agrarian subsistence economies, the rise of capitalism detached workers from the social networks of the old agrarian-artisanal world. If they became unemployed, urban factory workers were therefore left with virtually nothing. Certain institutional prerequisites for programme adoption are closely related to economic modernisation, notably labour statistics offices and employment exchanges. In other words, a critical threshold of economic development, a well-established legal framework and administrative capacities are crucial preconditions for the adoption of unemployment insurance.

\section{The Argument}

Given all these objections and requirements, the question arises when and under which conditions unemployment compensation schemes have been introduced. We argue that programme adoption is more likely (i) in economically developed nations and was (ii) crucially catalysed by the massively pressing problems generated by transnational shocks such as the two world wars and the Great Depression. As highly interdependent events these emergencies affected many countries simultaneously so that each crisis triggered a wave of welfare legislation. The crucial causal mechanism at the domestic level is that these emergencies generated massive unemployment and, in consequence, tremendous social need which forced governments to act. More specifically, severe crises can be conceptualised as shocks to risk pools (Rehm 2016). The fact that larger parts of the population were exposed to a higher risk of unemployment led to a growing demand for risk pooling, in other words, public social protection. The specific policy choices, however, depended on political factors (e.g. the power resources of labour) and existing institutional legacies.

Two qualifications are in order, however. First, the pressure caused by socio-economic problems varied with the extent to which a country was affected by these emergencies. In terms of war, for example, the number of war victims or the impact of war on the economy differed sharply depending on whether a country suffered from acts of war on its home territory, whether it was fighting in war theatres overseas or was not involved in combat at all (Obinger and Schmitt 2020). Second, the ways 
in which governments responded to these transnational emergencies also depended on whether or not unemployment insurance was already in place when a country was hit by an emergency. While depression and war should lead to welfare innovations in countries without unemployment compensation, retrenchment is more likely in countries which had already implemented unemployment insurance.

\section{$4 \quad$ Harbingers of Modern Unemployment Insurance}

The advent of national unemployment insurance did not occur in a vacuum but drew on the out-of-work benefit schemes set up by workers' associations and friendly societies in several highly industrialised countries (Kumpmann 1923). These institutions for mutual self-help exemplified that "insurance" against unemployment is in principle feasible. However, they also faced several difficulties ${ }^{1}$ which prompted state intervention at the local level. The crucial turning point was the economic depression in the late nineteenth century. Local state interference occurred in two forms: Municipalities either provided subsidies to the voluntary unemployment funds operated by workers' associations (a system that later became known as the Ghent system) or they established public insurance schemes. With regard to the latter, Swiss cities took the lead. However, these early experiments seemed to corroborate the critics of unemployment insurance. The unemployment insurance established in St. Gall in 1894 collapsed two years later, whereas the voluntary insurance in Bern introduced in 1893 suffered from adverse selection. Since the scheme only offered insurance against unemployment in wintertime, it mainly attracted construction workers and unskilled labourers. In consequence, an injection of public money was needed to avert a breakdown of the scheme.

The approach established by the Belgian city of Ghent in 1900 was much more successful. The municipality provided subsidies to the benefit payments made by unions which were tied to several conditions concerning eligibility and the level and duration of benefits. The Ghent system

\footnotetext{
${ }^{1}$ The main problem was that the contributions of workers alone were insufficient to finance adequate benefits.
} 
rapidly spread across European cities. Compared to mandatory insurance, it had several advantages. The Ghent system was appealing for employers because they did not have to contribute to its funding. Benefit provision by cities and unions also pacified agrarian interests which considered unemployment mainly an urban problem and therefore strictly opposed national insurance. The unions, by contrast, supported the Ghent system because it protected their autonomy and secured their control over the unemployment funds. From the state's point of view, the Ghent system was considered cheaper in terms of administration. As a result, the Ghent system was politically much less contested compared to public unemployment insurance. For most experts it was the "first successful method of organizing social unemployment insurance" (Rubinow 1913, 422; see also Gibbon 1911) and it is therefore not coincidental that the first national unemployment schemes relied on this model. France was the first country to adopt the Ghent system at the national level in 1905. Norway followed in 1907 and Denmark introduced the Ghent system one year later. Britain, by contrast, was the first country to introduce mandatory unemployment insurance in 1911, after state-run employment exchanges had been established in 1909. However, compulsory insurance was restricted to six trades characterised by frequent employment fluctuations. Benefits were flat-rate and the state covered one-third of the total costs.

However, these four pioneering national laws were mainly "experiments" (Franklin 1969, 294) and coverage was very low. In Norway, only 9000 workers were insured in 1907, the Danish scheme covered 105,000 workers in 1910 and the French system only included ca. 50,000 workers in 1913 (Obinger and Schmitt 2020). Even the British compulsory insurance only covered one-tenth of the labour force or 2.2 million workers.

\section{$5 \quad$ Black Swans and Unemployment Insurance Legislation up to 1950}

The major breakthrough for more comprehensive unemployment insurance schemes only emerged after nations were hit by national emergencies. By 1950, only 26 nations had established a national scheme. With 
Table 25.1 Introduction and type of unemployment compensation schemes, 1900-1950

\begin{tabular}{|c|c|c|c|}
\hline Early birds & World War I & $\begin{array}{l}\text { Great } \\
\text { Depression }\end{array}$ & World War II \\
\hline $\begin{array}{l}\text { France } 1905 \\
(1914)\end{array}$ & Netherlands 1916 & Sweden 1934 & Canada 1940 \\
\hline Norway 1906 & Finland 1917 & USA 1935 & $\begin{array}{c}\text { Australia } \\
1944\end{array}$ \\
\hline Denmark 1907 & Spain 1919 & $\begin{array}{l}\text { Yugoslavia } \\
1935\end{array}$ & Greece 1945 \\
\hline \multirow[t]{11}{*}{$\begin{array}{l}\text { UK } 1911 \text { (Ireland } \\
\text { 1922) }\end{array}$} & Italy 1919 (1918) & $\begin{array}{l}\text { South Africa } \\
1937\end{array}$ & $\begin{array}{c}\text { Japan } 1947 \\
(1945)\end{array}$ \\
\hline & Austria 1920 (1918) & $\begin{array}{l}\text { New Zealand } \\
1938\end{array}$ & \\
\hline & Belgium 1920 & & \\
\hline & Luxembourg 1920 & & \\
\hline & Czechoslovakia 1921 (1918) & & \\
\hline & Poland 1924 (1918) & & \\
\hline & Switzerland 1924 (1917) & & \\
\hline & Bulgaria 1925 & & \\
\hline & Germany 1927 (1918) & & \\
\hline & [Russia/Soviet Union & & \\
\hline & 1917/1922-1930] & & \\
\hline
\end{tabular}

Source: United States Department of Labor (1931); ILO (1955), own amendments Notes: Bold $=$ compulsory insurance; non-bold $=$ Ghent system; italics $=$ universal but targeted scheme. Years in brackets denote the introduction of unemployment assistance. The Soviet Union abolished its scheme by decree in October 1930. Apart from ideological motives this was mainly due to labour shortages in a period of rapid industrialisation and efforts to strengthen work discipline (see Rimlinger 1971, 270-271)

the exception of Japan, all were European countries or settler societies. Table 25.1 illustrates that programme adoption occurred in three waves which, in line with our argument, are closely related to three national emergencies. The first and biggest wave of programme adoption was unleashed by World War I. ${ }^{2}$ The second trigger was the Great Depression

\footnotetext{
${ }^{2} \mathrm{~A}$ further outcome of the war was the establishment of the International Labour Organization (ILO). Already at its first General Conference in 1919 the ILO recommended the introduction of unemployment insurance and free employment exchanges. Technical advice by ILO experts and international information exchange were important factors underlying the spread of unemployment insurance.
} 
and the last group of countries introduced unemployment insurance during and after World War II. ${ }^{3}$

\subsection{The Great War and Its Aftershocks}

If we look at the belligerent countries entering the Great War without unemployment insurance, we find a consistent pattern: All countries (including the successor states that emerged from collapsed empires) that experienced combat activities on their home territory (Italy, Austria, Russia, ${ }^{4}$ Bulgaria, Germany, Belgium, Poland and Czechoslovakia) adopted unemployment insurance after the Great War. ${ }^{5}$ Typically, programme adoption occurred in two steps. Immediately after demobilisation, a means-tested emergency benefit was introduced which later was replaced by compulsory insurance or a Ghent system. In several countries (e.g. Germany, Poland, Czechoslovakia), however, insurance legislation and law enforcement were postponed for some years due to a severe political and economic crisis and/or state-building.

However, also non-belligerent and mostly smaller European countries introduced insurance during or after the Great War. Although not involved in combat, war had a negative impact on their export-oriented economies through trade distortions caused by military conflict. The Netherlands adopted a Ghent system in 1916 in response to mounting unemployment (Brok 2012, 348). Neutral Switzerland, encircled by four belligerent nations, also suffered from war-induced trade distortions and unemployment continuously increased. In 1917, the federal government provided subsidies to local unemployment funds. What had started as a provisional wartime solution became federal law in 1924 against the

\footnotetext{
${ }^{3}$ See Obinger and Schmitt (2020) for an econometric study on the impact of war on the introduction of unemployment insurance. Apart from war intensity, left-wing governments were identified as driving forces for programme adoption.

${ }^{4}$ In Russia the Bolshevik revolution meant the end of the Russian war effort. Unemployment compensation was the first social protection scheme that was introduced by the Bolshevik regime on 11 December 1917 (Gregorian calendar). In practice, it remained mainly a dead letter due to war communism and severe economic crisis (Rimlinger 1971, 259-260).

${ }^{5}$ In sharp contrast, nations fighting in war theatres overseas such as the United States, Canada and the Antipodes did not enact unemployment insurance legislation at all. The economies in these nations were booming in wartime and the economic aftershocks of warfare were less dramatic.
} 
backdrop of post-war depression. ${ }^{6}$ In Finland the political and economic turbulences of the Bolshevik Revolution and the end of the Russian war effort caused a massive economic crisis with unprecedented levels of unemployment. The layoffs in the war industries (70,000 workers) and the economic crisis prompted the introduction of a Ghent system in November 1917. However, the scheme had no major practical relevance in the inter-war period due to the huge agricultural sector.

The development in countries that had already introduced a rudimentary national unemployment scheme before the war also supports our argument that crisis triggers welfare state expansion. Denmark and Norway raised state subsidies in wartime, whereas the French Ghent system was replaced in August 1914 by a means-tested scheme in response to military mass mobilisation and the related shutdown of factories. In Britain, compulsory unemployment insurance was extended to $1.4 \mathrm{mil}$ lion workers in the munitions industry in 1916. During military demobilisation, the government introduced a temporary and non-contributory out-of-work donation for discharged servicemen. Since this benefit was more generous than the ordinary insurance benefit, the out-of-work donation paved the way for a major reform of unemployment insurance law in 1920 which extended coverage to more than eleven million workers. Dependents' benefits were introduced in 1921.

\subsection{The Great Depression}

The second wave of inaugural legislation occurred in the wake of the Great Depression. The crash of the US stock market in 1929 set off shock waves around the world and led to a dramatic increase in unemployment which not only put policymakers under pressure but also changed the political landscape. In Northern Europe, the crisis gave rise to corporatist agreements in industrial relations which were mirrored by cross-class coalitions between left-wing and agrarian parties. Against this backdrop, Sweden (1934) introduced a Ghent system, Norway switched to compulsory insurance in $1938,{ }^{7}$ whereas Denmark extended state intervention

\footnotetext{
${ }^{6}$ In addition, several cantons declared unemployment insurance mandatory.

${ }^{7}$ This led to a tenfold increase in coverage.
} 
and made unemployment benefits more generous (Edling 2006). Unemployment insurance in the United States was introduced as part of the New Deal. Established under the Social Security Act in 1935 it was, in essence, a state-regulated but federally funded scheme. Rehm (2016) shows that the programme adoption at state level (stretching from 1932 to 1937) occurred earlier in states where many people faced a higher unemployment risk. ${ }^{8}$ In New Zealand, a largely unsuccessful work relief programme was enacted in 1930 to cope with economic crisis. In 1935, a Labour government took power for the first time and passed the pathbreaking Social Security Act in 1938 which, among other things, introduced universal but income-tested and tax-financed unemployment benefits. The Great Depression also prompted policy change in Canada. However, federal unemployment insurance was declared unconstitutional in 1936. Yugoslavia introduced unemployment benefits in 1935. South Africa enacted compulsory unemployment insurance in 1937, which was strongly modelled on the British scheme. However, coverage was restricted to eight industries and the law included racial discrimination as native workers were excluded from insurance.

In many nations that had already introduced comprehensive compulsory unemployment insurance, mass unemployment led to ballooning welfare costs. Here, the reaction was dramatically different and government ideology played a major role. In Germany and Austria, the political response to the Great Depression was austerity and right-wing governments imposed harsh benefit cutbacks, which contributed to political radicalisation and eventually to the demise of democracy. The Italian scheme was already dismantled by the Fascists in the 1920s. In Britain, spending on unemployment benefits skyrocketed but the Labour cabinet refrained from cutbacks. In 1931, a National Coalition Government imposed benefit cuts of 10 percent by decree, raised contributions and introduced a means test for the so-called transitional benefit. These changes were revoked under a new unemployment insurance law in 1934. Two years later, however, unemployment insurance for agricultural workers was established (Gilbert 1970, 175-182).

\footnotetext{
${ }^{8}$ In Rehm's terminology, programme adoption occurred earlier in states where risk inequality was lower.
} 


\subsection{World War II}

World War II unleashed the third wave of unemployment insurance legislation. In Australia and Canada, the federal governments lacked jurisdiction in this field before the war. This was why the first attempt to introduce unemployment insurance failed in 1936 in Canada. In both federations war was the crucial pacemaker for policy change. While previous attempts in Canada to amend the British North America Act had repeatedly failed, a consensus for a constitutional revision was reached in wartime and compulsory unemployment insurance was enacted in 1940. A similar pattern can be found in Australia. In contrast to the Great War, when voluntary Australian and New Zealand Army Corps (ANZAC) forces fought in war theatres overseas, the Pacific War increased the threat of a Japanese invasion. The danger of a homeland war prompted a significant extension of the Commonwealth's policy jurisdictions. Among other things, tax-funded unemployment benefits were introduced in 1944. As in New Zealand, this scheme provided income-tested and flat-rate benefits to all needy residents of working age. In Japan, the introduction of unemployment insurance resulted from a coercive policy transfer imposed by the US military government. To cope with high unemployment and widespread destitution after the end of war, an unemployment allowance was introduced as a temporary relief measure (Blaustein and Craig 1977) and was eventually replaced by unemployment insurance in late 1947 . Greece introduced unemployment insurance in 1945, it initially remained restricted to the Athens region but was later extended to other regions and professions (ILO 1955). Finally, Belgium switched from the Ghent system to mandatory insurance in late 1944.

\section{Conclusion}

This brief overview of the historical emergence of unemployment insurance in the first half the twentieth century has shown that programme adoption was closely connected to warfare and economic crisis. These transnational episodes of violence and economic decline simultaneously 
affected many countries. Mass unemployment generated by these emergencies caused tremendous social need. Workers and unions pushed for reforms and liberal and left-wing governments were more responsive to these pressures. The magnitude of the pressure from socio-economic problems and the aftershocks of war and depression, such as political instability and revolutionary threats, weakened the opponents of unemployment insurance and opened a window of opportunity for welfare state expansion. In addition, mass unemployment prompted ideational change and a paradigm shift in economic thinking: unemployment could no longer be considered voluntary, and Keynesianism challenged the classic view that market mechanisms always clear the labour market.

However, in the first half of the twentieth century the adoption of unemployment compensation remained restricted to less than thirty economically developed countries. Even today only ca. 50 percent of countries in the world have adopted this programme and most of them did so in the aftermath of a national emergency (Rehm 2016; Obinger and Schmitt 2021). The spread of unemployment insurance after 1950 reveals a clustering of legislative activities around major macro-economic crisis or regime transformations such as the breakdown of the Eastern bloc in the 1990s. More recently, the massive increase in unemployment generated by the COVID-19 pandemic has also triggered reforms related to the level and duration of unemployment benefits in several countries (Moreira and Hick 2021).

Acknowledgements This chapter is a product of the research conducted in the Collaborative Research Center "Global Dynamics of Social Policy" at the University of Bremen. The centre is funded by the Deutsche Forschungsgemeinschaft (DFG, German Research Foundation)_project number 374666841-SFB 1342. 


\section{References}

Alber, Jens. 1981. Government Responses to the Challenge of Unemployment: The Development of Unemployment Insurance in Western Europe. In The Development of Welfare States in Europe and America, ed. Peter Flora and Arnold J. Heidenheimer, 151-183. New Brunswick: Transaction Books.

Blaustein, Saul J., and Isabel Craig. 1977. An International Review of Unemployment Insurance Schemes. Kalamazoo: W.E. Upjohn Institute for Employment Research.

Brok, Anja. 2012. Only in Times of Crisis? Unemployment Policy in Germany and the Netherlands, 1914-1918. Australian Journal of Politics and History 58: 340-352.

Castles, Francis G. 2010. Black Swans and Elephants on the Move: The Impact of Emergencies on the Welfare State. Journal of European Social Policy 20 (2): 91-101.

Edling, Nils. 2006. Limited Universalism. Unemployment Insurance in Northern Europe 1900-2000. In The Nordic Model of Welfare. A Historical Reappraisal, ed. Niels F. Christiansen, Nils Edling, and Klaus Petersen, 99-143. Copenhagen: Museum Tusculaneum Press.

Gibbon, Ioan G. 1911. Unemployment Insurance. A Study of Schemes of Assisted Insurance. London: P. S. King and Son.

Gilbert, Bentley B. 1970. British Social Policy 1914-1939. London: B.T. Batsford. ILO. 1955. Unemployment Insurance Schemes. Geneva: ILO.

Kumpmann, Karl. 1923. Arbeitslosigkeit und Arbeitslosenversicherung. In Handwörterbuch Staatswissenschaften, ed. Ludwig Elster, Adolf Weber, and Friedrich Wieser, vol. 1, 791-824. Jena: Gustav Fischer.

Moreira, Amilcar, and Rod Hick. 2021. COVID 19, the Great Recession and Social Policy: Is this time different? Social Policy \& Administration 2021: 1-19. Obinger, Herbert, and Carina Schmitt. 2020. Total War and the Emergence of Unemployment Insurance in Western Countries. Journal of European Public Policy (online first). https://doi.org/10.1080/13501763.2019.1696388.

Obinger, Herbert, and Carina Schmitt. 2021. Unemployment insurance in the Global South since 1950: Drivers of policy adoption. In Global Social Policy (online first). October. https://doi.org/10.1177/14680181211049654.

Rehm, Philipp. 2016. Risk Inequality and Welfare States. Social Policy Preferences, Development, and Dynamics. Cambridge: Cambridge University Press.

Rimlinger, Gaston V. 1971. Welfare Policy and Industrialization in Europe, America, and Russia. New York: Wiley \& Sons. 
Rubinow, I.M. 1913. Subsidized Unemployment Insurance. Journal of Political Economy 21 (5): 412-431.

Schaertlin, Gottfried. 1904. Fürsorge für Arbeitslose, Besonders die Frage einer Versicherung gegen Arbeitslosigkeit. Sozialer Fortschritt. Hefte und Flugschriften für Volkswirtschaft und Sozialpolitik 1 (9): 1-16.

Stewart, Bryce M. 1932. Some Phases of European Unemployment Insurance Experience. Proceedings of the Academy of Political Science 14 (4): 35-56.

United States Department of Labor. 1931. Unemployment-Benefit Plans in the United States and Unemployment Insurance in Foreign Countries. Washington, DC: United States Government Printing Office.

Open Access This chapter is licensed under the terms of the Creative Commons Attribution 4.0 International License (http://creativecommons.org/ licenses/by/4.0/), which permits use, sharing, adaptation, distribution and reproduction in any medium or format, as long as you give appropriate credit to the original author(s) and the source, provide a link to the Creative Commons licence and indicate if changes were made.

The images or other third party material in this chapter are included in the chapter's Creative Commons licence, unless indicated otherwise in a credit line to the material. If material is not included in the chapter's Creative Commons licence and your intended use is not permitted by statutory regulation or exceeds the permitted use, you will need to obtain permission directly from the copyright holder.

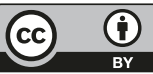

